\title{
GENOCIDE BY ANY OTHER NAME
}

\author{
John Maynard
}

In this essay I step back from contemporary discussions, observations and debates around the history of Australian genocide and reveal: a) the words of policymakers and officials during the late nineteenth century about the treatment of Aboriginal people; b) the recognition of genocidal acts in newspaper coverage of the early twentieth century; and c) the assertions of prominent early Aboriginal activists, including my grandfather Fred Maynard, on the violence meted out to Aboriginal people. Neither officials nor Aboriginal activists used the term "genocide" of course, since it had not yet been coined. The terminology they used, however, aligns with a contemporary understanding of genocide. These witnesses and observers were well aware of the genocidal practices occurring during their own time.

Settler colonial societies, including Australia, continue to struggle in the twenty-first century to deal with the crimes of their forebears, crimes that impacted so devastatingly on Indigenous peoples. For the greater part of the twentieth century, Aboriginal people simply did not figure in Australia's celebratory and triumphalist history. The descent of the curtain of silence during this period, which prevented government officials or media from reporting on Australia's treatment of Aboriginal people, was described by the late anthropologist W.E.H. (Bill) Stanner as the "Great Australian Silence."1

Yet in the early decades of the twentieth century, Aboriginal activists, despite coming from a marginalised minority, raised their voices and protested the crimes against their communities. Their outspoken comments, echoed in the cries of their non-Aboriginal supporters, were not just confined to the atrocities committed on the frontier. They also recognised that government policy introduced at the start of the twentieth century would unquestionably lead to one result — genocide. In this paper, I recall comments made to me by Dungatti elder, Uncle Reuben Kelly, about those brave Aboriginal activists.

After that first wave of Aboriginal activism, the 1960s and 1970s saw the re-emergence of grassroots movements and a new generation of young histori-

1 W.E.H. Stanner, “The Boyer Lectures: After the Dreaming,” The Dreaming and Other Essays (Melbourne: Black Inc. Agenda, 2009), 182-93. 
ans who began to unpack the history of the continent post-1788 and recognise the destruction wrought upon Aboriginal Australia. Inspired by Stanner and historian Charles Rowley, others like Henry Reynolds, Noel Loos, Bob Reece, Raymond Evans and Lyndall Ryan heeded the call and lifted the veil on historical violence and massacres. ${ }^{2}$ At the same time, Aboriginal viewpoints seeped into the public domain, from activists like Kevin Gilbert and Charlie Perkins.

As had happened earlier, this historical reality check was subsequently followed and challenged by politicians, journalists and scholars who were more inclined to support the celebratory national history of the past, one that recognised discoverers, explorers and settlers, and presented the more palatable view that Australia was peacefully settled. These debates, challenges, arguments and disputes continue to echo across this historical divide even today.

The claim of "genocide” often triggers such debate. In its landmark Bringing Them Home Report, the Australian Human Rights Commission argued that the forced removals of Aboriginal children over the nineteenth and twentieth centuries constituted a genocidal policy. Strongly and publicly recognising Australia's history of genocide, Colin Tatz has many times applied the terms of the UN Genocide Convention to Australia, noting that actions taken against Indigenous peoples were calculated, wanting to destroy and/or to cause serious physical and mental harm, and that the forcible removal of children conformed to the acts of genocide defined in the Convention. ${ }^{3}$ Tatz later reflected that his disclosures upset many people who "were duly shocked, upset and bewildered by this portrait of Australia as a genocidal society."4

\section{The recognised guilt in the records}

Before Australia's Great Silence and subsequent rewriting of history to portray Australia as having been peacefully settled, many colonial and British government officials, legislators and politicians openly asserted Australia's role in the destruction of Aboriginal communities, and newspapers openly reported it. The Secretary of State for War and the Colonies, Lord Glenelg, between

2 Noel Loos, “Aboriginal-European Relations in North Queensland, 1861-1897” (PhD thesis, James Cook University, 1976); Noel Loos, “Frontier Conflict in the Bowen District, 1861-1874” (PhD thesis, James Cook University, 1970); Henry Reynolds, The Other Side of the Frontier (Melbourne: Penguin Books, 1982); Raymond Evans, Kay Saunders and Kathryn Cronin, Exclusion, Exploitation and Extermination: Race Relations in Colonial Queensland (Sydney: Australia \& New Zealand Book Co., 1975); Lyndall Ryan, The Aboriginal Tasmanians (Sydney: Allen \& Unwin, 1996); Robert Reece, Aborigines and Colonists (Sydney: Sydney University Press, 1974).

3 Colin Tatz, With Intent to Destroy: Reflecting on Genocide (London: Verso, 2003), 72.

4 Colin Tatz, Human Rights and Human Wrongs: A Life Confronting Racism (Melbourne: Monash University, 2015), 305. 
1835 and 1839 was blunt in his assessment: "Let us not cast upon Heaven a destruction which is our own, and say the [A]boriginals are doomed by Divine Providence when the guilt lies with ourselves." 5 In official despatches, Lord John Russell-a powerful government official and twice British Prime Minister-was also forthright on where the guilt lay for the treatment of the Aboriginal population: "All too clear is the truth that from first to last the line of contact of the two races has been a red one, and the strong Caucasian has trodden the naked nomad like mire into his own soil." ${ }^{6}$ In a later despatch, Russell would add that it was "impossible to contemplate the condition and the prospects of that unfortunate race without the deepest commiseration."7

Before the House of Commons Committee in 1838, Lieutenant Richard Sadlier $^{8}$ highlighted with alarm the dire situation in the Australian Colonies: "As a question of humanity nothing can be more dreadful to contemplate, or more disgraceful to a Christian and civilised nation, than the wholesale destruction going on for the last fifty years, and must continue to the end unless some plan is devised to prevent it."9 Sadlier recognised Aboriginal people as sovereign holders of their land and his statements clearly describe colonial actions as a war of destruction with the aim of usurping the land. Contemporary scholarship of genocide often focuses on factors such as land expropriation and "cleansing" of minorities who stand in the way of colonial expansion. Sadlier was reported to have written:

It might be presumed that the natives of any land have an incontrovertible right to their own lands, as it is a plain and sacred right which appears not to have been understood. Europeans have entered their border uninvited, and when there have not only acted as if they were the undoubted lords of the soil, but have punished the natives as aggressors if they have evinced a disposition to live in their own country. If the Australian [A]borigines have been found upon their own property, they have been hunted as thieves and robbers, driven back into the interior as if they were dogs or kangaroos. ${ }^{10}$

Evidence delivered to the 1838 House of Commons Committee on the Aboriginal plight horrified members. Lord Stanley wrote of his dismay: "Outrages of

5 Archibald Meston, “Vanishing Aboriginals,” Sydney Morning Herald, March 25, 1922.

6 Cited in Ibid.

7 Cited in Meston, "Vanishing Aboriginals."

8 K. J. Cable, “Sadlier, Richard (1794-1889),” Australian Dictionary of Biography (Canberra: National Centre of Biography, Australian National University, 1967).

9 Cited in Meston, "Vanishing Aboriginals."

10 Sydney Morning Herald, March 25, 1922. 
the most atrocious description, involving considerable loss of life are spoken of in these papers with an indifference and lightness which is very shocking."11 A journalist for the Newcastle Chronicle was adamant that:

We have not only taken possession of the lands of the [A]boriginal tribes of this colony, and driven them from their territories, but we have also kept up unrelenting hostility towards them, as if they were not worthy of being classed with human beings, but simply regarded as inferior to some of the lower animals of creation. ${ }^{12}$

There is no mistaking that these individuals witnessed and spoke of a war of extermination that had been unleashed against the Aboriginal population. This is only a small sample of material readily available.

\section{Early twentieth century media observations}

In the early twentieth century, journalists and commentators were forthright in their estimation of the treatment of Aboriginal people in Australia's historical past. One writer in the Sydney Morning Herald recognised not just the injustices of the newly federated nation's past, but also the grim future for the Aboriginal population: "Most of the white insurpers [sic] of this continent consider the blackfellow a lingering nuisance, whose inevitable demise should be hastened rather than retarded." ${ }^{13}$ Author T.P. Bellchambers impressed the crimes of the past upon the nation's memory:

It has been said that we acquired this country not by an act of war, but by peaceful occupation. Yes, without so much as "by your leave" we introduced ourselves as supermen and overlords; we took possession of the [A]borigines, destroyed their game and drove them from their scant water supplies ... our "peaceful occupation" has meant many treacherous deeds. ... We who have steeped our souls in every known sin, as judged by our laws that we have made. ${ }^{14}$

Aboriginal protection societies began in Britain in the nineteenth century, and similar bodies were established in Australia, gaining some momentum in

11 Sydney Morning Herald, March 25, 1922.

12 Newcastle Chronicle, November 18, 1869, 2.

13 Sydney Morning Herald, 1904.

14 Daylight, May 25, 1922. 
the 1930s. The progress associations, sometimes called welfare leagues, campaigned strongly for the end of discriminatory laws, better living conditions and the granting of full citizenship rights. They tried hard to gain media space and attention, but were seldom heard by the press and a public that did not want to listen. After World War Two, these bodies were dismissed as "dogooders" or worse, as Communists.

\section{Early Aboriginal activists and their supporters}

The Australian Aboriginal Progressive Association (AAPA) was formed in Sydney in 1924 and led by my grandfather, Fred Maynard (1879-1946), a Worimi Aboriginal man. Fred Maynard was an articulate and inspiring visionary. The AAPA was the first to make a pan-Aboriginal demand for a national land rights agenda, as well as advocating for self-determination. While the group itself comprised Aboriginal members, high profile non-Aboriginal people like missionary Elizabeth McKenzie-Hatton and newspaper editor John J. Moloney were active supporters.

In this section I analyse the commentary of Fred Maynard and supporters to reveal those grassroots Aboriginal movements and their understanding of a genocide being perpetrated. It is important to realise that early Aboriginal activists and their supporters were well aware of the sickening historical reality of violence perpetrated against Aboriginal populations. Their views consolidate the recognition of government officials and the media.

Fred Maynard was scathing in his assessment, not hesitating to label the British landing at Port Jackson in 1788 as an "invasion.” The British had, in his estimation, decimated the Aboriginal population through "the arts of war . .. and diseases.” In an interview I conducted over 20 years ago, Uncle Reuben Kelly, the respected Dungutti elder, shared his recollections of that time. Kelly was adamant that Fred Maynard was the first Aboriginal man "to speak out about the atrocities, the poisoning, the murders, and the penal system.” Kelly said he revealed "the condoned and silenced massacres of the past." 15 Maynard saw parallels between the experiences of Aboriginal people in Australia and the mass killings that had taken place in the Belgian Congo. ${ }^{16}$ While the numbers differed substantially, with the Congo witnessing a "death toll of holocaust dimensions," Maynard saw a similar genocidal intent in Australian government policy. In relation to New South Wales government policy that he

\footnotetext{
15 Reuben Kelly, in discussion with John Maynard, 1996.

16 Adam Hochschild, King Leopold's Ghost: A Story of Greed, Terror and Heroism in Central Africa (London: Pan Books, 2006), 3.
} 
foresaw as having drastic ramifications on local Aboriginal people, he wrote: "What a horrible conception of so called legislation, Re any civilised laws, I say deliberately stinks of the Belgian Congo."17

The language Maynard uses to describe the government's treatment of Aboriginal people aligns with the legal definition of genocide. In his estimation, the situation facing Aboriginal peoples and their continuation as a community, was dire.

Maynard saw the government policy of separating young Aboriginal children from their families, especially the girls, as part of a genocidal policy, stating that this "objectionable practice of segregating the sexes as soon as they reach a certain age should be abolished for it meant rapid extinction."18 He viewed the New South Wales Aborigines Protection Board and the Aborigines Act, as well as the Board's so-called apprenticeship scheme as nothing more than a thinly disguised "attempt to exterminate the race." ${ }^{19}$ Maynard was not alone in his assessment of this callous treatment with non-Aboriginal commentators also voicing their disapproval. Richard Tomalin, manager of Mount Leonard cattle station at Windorah in Queensland, wrote to the AAPA leadership and offered his support:

It is not necessary to give my personal experience connected with some appalling extermination methods bar the fact that their [Aboriginal] numbers were reduced not by the procedure of time, but by drastic unlawful methods adopted by the white settlers. ${ }^{20}$

He observed the horror of assaults upon Aboriginal family life:

The drastic and utterly unlawful method of taking away their female children would not stand if taken direct to a British Tribunal, as under the law the freedom of a British subject cannot be taken from him, and I consider a father just as much justified in using all means he chooses to defend his children from being forcibly removed from their parental care, more so even than a banker defending his gold. ${ }^{21}$

Two prominent and courageous non-Aboriginal supporters of the early Abo-

17 Fred Maynard, private letter, NSW Premiers Department Correspondence Files, A27/915, 1927.

18 Cited in John J. Moloney, “The Aboriginals,” Voice of the North, December 10, 1926.

19 “Aborigines: Agitation by Association,” Northern Star, August 3, 1927.

20 Richard Tomalin, “Australian Aboriginals,” Voice of the North, June 10, 1927, 18.

21 Ibid. 
riginal political movement were the missionary Elizabeth McKenzie Hatton and John J. Moloney, the Editor of the Newcastle newspaper the Voice of the North. Decades ahead of their time, their words remain powerful today in challenging whitewashed Australian history. Former Prime Minister John Howard argued that, "Australians of the current generation should not be required to accept blame for past policies over which they had no control."22 Yet McKenzie Hatton, writing in the Daylight in 1926, could almost be replying to Howard across the decades:

We may claim that we are not responsible for the actions of the original British invaders who violated their homes, shot, poisoned, burned and mutilated the natives, but we cannot claim immunity from the conditions existing at the present time, and what should not be tolerated for one moment longer than it will take to rectify matters. The citizens comfortably situated on the shores of Port Jackson are, in the main, absolutely ignorant of the conditions under which the natives are existing. The moment this sore is opened up there will be a rush of apologists from the ranks of parliamentarians, parsons, priests, pedagogues, pedants, and peripatetic philosophers, but such belated excuses will be brushed aside, for the fiat has gone forth-JUSTICE TO THE NATIVES—and the people of Australia will not be satisfied until that full measure of compensation has been accorded to a much injured and sadly wronged people. ${ }^{23}$

This illustrates how, in the contemporary setting, the failure to accept any blame or responsibility has continued unabated, notwithstanding Paul Keating's 1992 Redfern speech and Kevin Rudd's apology to the Stolen Generations. Contemporary scholar Dirk Moses points out that the British "understood the effects of their presence in Australia" but, nevertheless, demonstrated an inability to take "responsibility for the anticipated disappearance of the Aboriginal peoples, despite the obvious connection between colonization and depopulation.,24

22 John Howard, Lazarus Rising: A Personal and Political Autobiography (Sydney: Harper Collins, 2010), 277.

23 Elizabeth McKenzie Hatton, “The Dark Brethren,” Daylight, October 30, 1926, 102.

24 A. Dirk Moses, ed., Genocide and Settler Society: Frontier Violence and Stolen Indigenous Children in Australian History (New York: Berghahn Books, 2005), 6. 


\section{Conclusion}

In a letter written in 1927, J.J. Moloney, a fierce Australian nationalist, spoke out about the treatment of Aboriginal people:

The iniquity of the position maddens me. To see these poor creatures kicked into the bush-worse than dogs - their homes built by their own hands confiscated, no compensation, no redress - their children kidnapped by the Crown and sent to work for Collins Whites at 6d a week, robbed at every turn, derided by all parties. . . . Every Church equally to blame-Priests, Bishops, Parsons - all equally guilty . . . if I were in London, I think I would try and get an audience with the King. ${ }^{25}$

While many historians, genocide scholars, journalists and politicians continue to debate and question the validity of whether genocide was committed in Australia, eyewitnesses had no doubt. Neither did Aboriginal people. I look back over my own family's history and that of the Worimi people of the Port Stephens region of New South Wales and realise that it is a miracle I am here today. The stark reality is that so many thousands of our people were swept away with no regard for them as human beings and, even deliberately, with genocidal intent.

If Australia is willing to accept this history and so educate our children, the evidence is here, waiting. Those who were alive at the time stated openly what they witnessed; government officials spoke honest words about the policy goal of extermination; newspapers wrote about it - the public cannot claim not to have known. Today we have a body of literature by Aboriginal and non-Aboriginal scholars that presents survivor testimony from members of the Stolen Generations and evidence of massacre and frontier warfare that resulted in large numbers of Aboriginal deaths. Aboriginal people spent decades with no legal or civil rights, no sense of belonging in Australia. In the whole menu of what constitutes "human rights," we did not have even one item. Moreover, we experienced and survived a genocide that, while clearly acknowledged at the time, remains hidden today. It is with the aim of revealing that genocide that the words of my grandfather, Fred Maynard, resonate still: the government "insulted and degraded all Aboriginal people, and it aimed to exterminate the noble and ancient race of sunny Australia.,26 